\title{
Formulasi Strategi Penghimpunan Zakat oleh Badan Amil Zakat Nasional (BAZNAS)
}

\section{Strategy Formulation of Zakat Collection by The National Amil Institution (BAZNAS)}

\author{
Ita Aulia Coryna ${ }^{1}$, Hendri Tanjung ${ }^{2}$ \\ ${ }^{1}$ Mahasiswa Pascasarjana SB IPB, Email: ita.aulia.coryna@gmail.com \\ ${ }^{2}$ Dosen Pascasarjana SB IPB, Email: hendri.tanjung@gmail.com
}

\begin{abstract}
As the most populous Muslim nation in the world Indonesia has the largest zakat potential, yet its' zakat collection on national level only reached $1 \%$ of the whole potential. This matter has become the greatest challenge for all zakat institutions in Indonesia, especially the National Amil Institution (BAZNAS). Recently the government made a new regulation; Inpres No.3/2014, that could help the institution to minimize the discrepancy between zakat potential and zakat realization. The main objective of the paper is to formulate a strategy for BAZNAS to optimized its zakat fund's collection in regards to the new regulation, where BAZNAS is specifically asked to coordinate and to collect zakat from all of government's institutions. Data is collected using a survey questionnaire on both internal and external representatives of BAZNAS, and is analyzed using SWOT matrix.
\end{abstract}

Keywords : BAZNAS, Strategy, SWOT, Zakat, Zakat collection

Abstrak. Sebagai negara dengan jumlah populasi Muslim terbanyak di dunia, Indonesa mempunyai potensi zakat terbesar, tetapi pada penghimpunan zakat di tingkat nasional hanya memperoleh $1 \%$ dari total potensinya. Hal ini menjadi tantangan terbesar untuk semua institusi zakat yang ada di Indonesia, terutama bagi Badan Amil Zakat Nasional (BAZNAS). Saat ini pemerintah telah membuat suatu kebijakan baru, yaitu Inpres No 3/2014 yang membantu organisasi untuk meminimalisasi ketimpangan antara potensi zakat dan realisasi zakat. Tujuan utama dari tulisan ini adalah untuk memformulasi suatu strategi untuk BAZNAS mengoptimasisasi dana pengumpulan zakat dalam peraturan baru, dimana BAZNAS mengkoordinasikan untuk mengumpulkan zakat dari semua lembaga pemerintah. Data dikumpulkan melalui survey dan kuesioner dari pihak internal dan eksternal BAZNAS dan menggunakan analisis matrik SWOT.

Kata kunci: BAZNAS, Strategi, SWOT, Zakat, Penghimpunan Zakat

\section{Pendahuluan}

\subsection{Latar Belakang}

Indonesia merupakan negara dengan penduduk muslim terbesar di dunia, dan merupakan negara yang memiliki potensi zakat yang terbesar pula. Hal ini ditunjukkan oleh hasil penelitian yang dilakukan atas kerjasama antara BAZNAS dan Fakultas Ekonomi Manajemen Institut Pertanian Bogor. Seperti yang digambarkan oleh Tabel 1, hasil riset tersebut menemukan bahwa potensi zakat nasional pada tahun 2011 mencapai angka 3,4 persen dari total Produk Domestik Bruto (PDB), atau dengan kata lain potensi zakat di Indonesia setiap tahunnya tidak kurang dari Rp 217 triliun. 
Tabel 1 Potensi Zakat Nasional

\begin{tabular}{clcc}
\hline No. & \multicolumn{1}{c}{ Jenis Zakat } & $\begin{array}{l}\text { Jumlah } \\
\text { (Rp Trilliun) }\end{array}$ & $\begin{array}{l}\text { Prosentase terhadap } \\
\text { PDB }\end{array}$ \\
\hline 1 & Zakat Rumah Tangga (Individu) & 82,10 & 1,30 \\
2 & Zakat Industri: & 114,89 & \\
& Zakat Perusahaan Swasta & 2,40 & \\
& Zakat BUMN & & \\
& & 117,29 & 1,84 \\
& Sub Total & 17,01 & 0,27 \\
3 & Zakat Tabungan & 217,0 & 3,40 \\
\hline
\end{tabular}

Sumber : Baznas \& FEM IPB (2011)

Nilai potensi ini tentu sangat mengejutkan, namun sayangnya potensi besar ini tidak dibarengi dengan realisasi penghimpunan zakat yang besar pula. Realisasi penerimaan zakat nasional pada tahun 2011 hanya sekitar satu persen saja dari keseluruhan potensi, yaitu sebesar 1,8 Trilliun rupiah, seperti yang diperlihatkan pada table 2 berikut ini.

Tabel 2 Penghimpunan ZIS Nasional 2007-2012

\begin{tabular}{cc}
\hline Tahun & Penghimpunan Aktual Zakat (Rp) \\
\hline 2007 & $740,000,000,000$ \\
2008 & $920,000,000,000$ \\
2009 & $1,200,000,000,000$ \\
2010 & $1,500,000,000,000$ \\
2011 & $1,800,000,000,000$ \\
2012 & $2,730,000,000,000$ \\
\hline
\end{tabular}

Rukmana (2014)

Walaupun terjadi peningkatan penerimaan zakat menjadi Rp. 2,73 trilliun pada tahun 2012, tetap masih terdapat kesenjangan yang sangat tinggi antara potensi dan aktualisasi penghimpunan zakat nasional. ${ }^{1}$ Tabel 1 dan 2 menunjukkan bahwa pengelolaan dana zakat di Indonesia masih jauh dari optimal. Maka untuk mengatasi masalah kesenjangan antara potensi dan aktualisasi zakat tersebut diperlukan strategi penghimpunan dana zakat yang efektif agar seluruh potensi zakat yang ada dapat dioptimalkan. Namun dalam mencapai tujuan tersebut tentunya diperlukan kerjasama program dan integrasi nasional antara pengelola zakat dan pemerintah sebagai regulator.

Dalam rangka mewujudkan hal tersebut pemerintah Indonesia baru-baru ini mengeluarkan Inpres No. 3 tahun 2014, dimana dalam Inpres ini Presiden menginstruksikan kepada seluruh lembaga atau badan milik pemerintah agar berkordinasi dengan Badan Amil Nasional (BAZNAS) untuk mensosialisasikan

${ }^{1}$ Didin Hafidhuddin : Potensi Zakat Terserap Satu Persen, dalam Republika Online, 29 April 2013. 
dan juga menumbuhkan kesadaran wajib zakat kepada seluruh karyawan Muslim di institusi masing-masing, sekaligus memfasilitasi para karyawan tersebut untuk membayar zakat melalui BAZNAS.

Jika dilaksanakan dengan baik dan maksimal, kehadiran Inpres ini akan sangat menguntungkan karena dapat membantu BAZNAS meminimalisasi kesenjangan perhimpunan zakat yang baru terserap sekitar satu persen. Kini masalah yang dihadapi adalah bagaimana memformulasikan strategi yang tepat agar implementasi Inpres No.3/2014 berjalan dengan lancar dan mendapatkan hasil sesuai harapan. Secara nasional maupun global belum ada strategi khusus yang diformulasikan dan diikuti oleh seluruh lembaga zakat dalam menghimpun potensi dana zakat yang ada.

Jika BAZNAS berhasil menjalankan Inpres No.3/2014 melalui sistem atau strategi penghimpunan dana zakat yang efektif, selain akan meningkatkan penghimpunana zakat nasional hal ini juga akan bermuara pada tumbuh dan terpeliharanya kepercayaan masyarakat serta meningkatnya manfaat zakat untuk peningkatan kesejahteraan umat dan penanggulangan kemiskinan. Pada saat yang sama, pengelolaan zakat yang dilakukan secara amanah dan profesional menunjukkan kepada masyarakat betapa peran zakat sebagai solusi masalah keumatan bukan hanya sebuah wacana saja tapi sebuah kenyataan.

\subsection{Perumusan Masalah}

Berdasarkan pendahuluan dan latar belakang di atas, maka rumusan masalah penelitian ini adalah sebagai berikut : (1) Apa saja kekuatan dan kelemahan internal yang dimiliki oleh BAZNAS dalam menjalankan Inpres No. 3/2014?. (2) Apa saja peluang dan ancaman external yang dihadapi oleh BAZNAS dalam menjalankan Inpres No.3/2014?. (3) Langkah-langkah strategis apa yang harus dilakukan oleh BAZNAS agar proses penghimpunan dana zakat sesuai Inpres No.3/2014 berjalan dengan efektif?

\subsection{Tujuan Penelitian}

Tujuan penelitian didasarkan pada rumusan masalah yang telah dijelaskan di atas, adalah sebagai berikut : 1) Menganalisa kekuatan dan kelemahan internal yang dimiliki oleh BAZNAS terkait Inpres No. 3/2014. 2) Menganalisa peluang dan ancaman external yang dihadapi oleh BAZNAS terkait Inpres No.3/2014. 3) Merumuskan strategi penghimpunan zakat yang efektif untuk BAZNAS terkait Inpres No.3/2014.

\subsection{Manfaat Penelitian}

Penelitian ini diharapkan dapat memberikan manfaat kepada manajemen BAZNAS sebagai masukan dan usulan dalam penyusunan strategi penghimpunan dana zakat terkait Inpres No.3/2014. Dan juga kepada para akademisi dan masyarakat umum dapat dijadikan sebagai studi pustaka dan bahan untuk pengkajian berikutnya. 


\subsection{Ruang Lingkup Penelitian}

Ruang lingkup penelitian ini adalah perumusan strategi penghimpunan zakat yang efektif untuk BAZNAS dalam rangka menjalankan Instruksi Presiden No.3 tahun 2014. Adapun implementasi strategi tidak termasuk lingkup penelitian dan diserahkan sepenuhnya kepada manajemen BAZNAS.

\section{Tinjauan Pustaka}

\subsection{Zakat}

Ditinjau dari segi bahasa, kata zakat mempunyai beberapa arti, yaitu al-barakatu (keberkahan), an-namaa (pertumbuhan dan perkembangan), ath-thaharatu (kesucian), dan ash-shalahu (keberesan). Sedangkan secara istilah, zakat adalah bagian dari harta dengan persyaratan tertentu yang Allah SWT mewajibkan kepada pemiliknya untuk diserahkan kepada yang berhak menerimanya, dengan persyaratan tertentu pula (Hafidhuddin, et al, 2013).

Orang yang berhak menerima zakat disebutkan dalam firman Allah di Al-Qur'an surat at Taubah ayat 60. Berdasarkan surat at-Taubah ayat tersebut terdapat delapan kelompok yang berhak menerima zakat yaitu fakir, miskin, amil zakat (lembaga pengelola zakat) orang yang baru masuk Islam (mualaf), untuk memerdekakan budak, orang-orang yang berhutang (gharimin), orang yang berjuang di jalan Allah (fi sabilillah), orang-orang yang sedang dalam perjalanan (ibnu sabil).

Telah terbukti secara empiris bahwa zakat dapat berfungsi sebagai instrumen yang berpengaruh positif terhadap kondisi ekonomi dan keuangan sebuah negara jika dikelola secara optimal (Hafidhuddin et al, 2013). Bahkan berbagai studi di Indonesia telah menunjukkan dampak positif pengelolaan zakat terhadap upaya pengentasan kemiskinan. Studi tersebut diantara lain dilakukan oleh Laela (2010), Beik (2013), Beik et al (2011) dalam buku Indonesia Zakat Development Report 2011, Minarti et al (2012) dalam buku Indonesia Zakat Development Report 2012, dan masih banyak studi lainnya.

\subsection{Pengelola Zakat}

Menurut UU No. 23 tahun 2011 lembaga pengelola zakat adalah lembaga yang melakukan kegiatan perencanaan, pelaksanaan, dan pengkoordiasian dalam pengumpulan, pendistribusian, dan pendayagunaan zakat. Adapun jenis lembaga pengelola zakat (LPZ) yang diakui pemerintah ada tiga jenis, yaitu:

a. Badan Amil Zakat Nasional (BAZNAS) adalah lembaga pengelola zakat yang dibentuk oleh pemerintah yang bertugas untuk melakukan pengelolaan zakat secara nasional.

b. Lembaga Amil Zakat (LAZ) adalah lembaga yang dibentuk oleh masyarakat yang memiliki tugas membantu pengumpulan, pendistribusian, dan pendayagunaan zakat.

c. Unit Pengumpulan Zakat (UPZ) adalah satuan organisasi yang dibentuk oleh BAZNAS untuk membantu pengumpulan zakat. 


\subsection{Manajeman Strategi}

Manajemen strategi dapat diidentifikasikan sebagai serangkaian keputusan dan tindakan manajerial yang menentukan kinerja perusahaan dalam jangka panjang (Wheelen dan Hunger, 2012). Manajemen strategis meliputi pengamatan lingkungan, perumusan strategi, implementasi strategi, dan evaluasi serta pengembalian. Manajemen strategis menekankan pada pengamatan dan evaluasi peluang dan ancaman lingkungan dengan melihat kekuatan dan kelemahan perusahaan.

\subsection{Proses Manajemen Strategi}

Manajemen strategis terdiri dari tiga proses yaitu perumusan strategi, penerapan strategi, dan penilaian strategi (David, 2011). Perumusan strategi mencakup pengembangan visi dan misi, identifikasi peluang dan ancaman dari luar, kesadaran akan kekuatan dan kelemahan perusahaan, penetapan tujuan jangka panjang, pencarian strategi-strategi alternatif, dan pemilihan strategi tertentu untuk mencapai tujuan. Proses selanjutnya adalah penerapan strategi, meliputi penentuan sasaran operasional tahunan, kebijakan perusahaan memotivasi karyawan dan mengalokasikan sumber daya agar strategi yang telah ditetapkan dapat diimplementasikan. Proses berikutnya adalah penilaian strategi, yaitu mengukur kinerja individu dan perusahaan serta mengambil langkah-langkah perbaikan jika diperlukan.

\subsection{Analisis SWOT}

Untuk merumuskan strategi maka organisasi harus memperhatikan analisis lingkungan eksternal dan internal. Analisis SWOT merupakan salah satu metode yang digunakan untuk menentukan peluang dan ancaman eksternal yang dihadapi organisasi dengan penyesuaian kekuatan dan kelemahan internal.

\subsection{Matriks Internal-Eksternal (IE Matrix)}

Matriks IE menggambarkan posisi perusahaan ke dalam kerangka kuadran yang terdiri atas sembilan sel, dimana matirks IE dibuat dengan menggunakan input dari hasil analisis faktor eksternal dan internal (David, 2011). Manfaat dari pemakaian metode matriks IE dalam manajemen strategi adalah untuk membantu perusahaan dalam melihat posisi perusahaan dan memudahkan perusahaan dalam merumuskan strategi yang paling efektif.

\subsection{Kajian Penelitian Terdahulu}

Penelitian terhadap BAZNAS dilakukan oleh Shalihati (2010) terkait persepsi muzakki yang membayar zakat melalui BAZNAS, lembaga lain dan non lembaga. Penelitian dilakukan selama 3 bulan di kantor pusat BAZNAS menggunakan metode multiatribut Fishbein, dimana hasil dari penelitian ini menemukan bahwa penilaian muzakki yang membayar zakat melalui lembaga lain terhadap BAZNAS adalah lebih baik dibandingkan dengan muzakki non lembaga. Sedangkan Jamil (2003), Siregar (2003) dan Rukmana (2014) melakukan penelitian terhadap lembaga zakat lain, yaitu Dompet Dhuafa Republika. Penilitian yang dilakukan Jamil (2003) bertujuan untuk menyusun arsitektur strategis LAZ Dompet Dhuafa 
Republika dengan menggunakan alat analisis matriks EFE, matriks IFE, PEST, Five Forces of Porter's, analisis rantai nilai, dan kompetensi inti.

Siregar (2003) juga melakukan penelitian terhadap Dompet Dhuafa Republika namun penelitian tidak bertujuan untuk memformulasikan suatu strategi, melainkan menganilisis kinerja lembaga tersebut sebagai lembaga pengelola dana ZISWAF. Alat analisis yang digunakan adalah empat perspektif Balanced Scorecard (BSC) yaitu perspektif keuangan, perspektif pelanggan, perspektif proses bisnis internal dan perspektif pertumbuhan dan pembelajaran. Sementara itu penelitian yang dilakukan Rukmana (2014) terhadap Dompet Dhuafa bertujuan untuk menganalisis kondisi internal dan eksternal lembaga agar pada akhirnya dapat memformulasikan strategi transformasi pada LAZ tersebut. Formulasi strategi pada penelitian ini juga dirumuskan dengan menggunakan matriks IFE, matriks EFE, matriks IE dan matriks SWOT sebagai alat analisis. Menurut temuan penelitian ini, pemicu terbesar pendorong perubahan eksternal lembaga zakat adalah meningkatnya kesadaran wajib zakat masyarakat, dan juga perubahan regulasi dari pemerintah.

Untuk menunjang penelitian strategi maka merujuk kepada penelitian yang dilakukan oleh Anggorojati (2014), Purnama (2014) dan juga Pambudi (2013) dimana penelitian ini bertujuan untuk menganalisis faktor-faktor strategis internal dan eksternal organisasi dan memformulasikan strategi untuk memenangkan persaingan dan mencapai target dan tujuan perusahaan. Metode analisis yang digunakan dalam mengevaluasi faktor-faktor strategis internal dan eksternal perusahaan pada tiga penelitian tersebut adalah matriks IFE, matrik EFE, matirks IE dan matriks SWOT. Strategi-strategi alternatif yang ditemukan kemudian dirumuskan menggunakan analisis SWOT yang kemudian dianalisis lagi menggunakan QSPM untuk memberikan arahan agar perusahaan mampu menjalankan strategi-strategi secara tepat dan konsisten sesuai tahapan-tahapan yang direkomendasikan.

\section{Metode Penelitian}

\subsection{Tempat dan waktu penelitian}

Penelitian dilakukan di daerah Jakarta, Bogor dan sekitarnya, termasuk di kantor pusat BAZNAS, Jl. Kebon Sirih Raya No. 57, Jakarta Pusat. Waktu penelitian dilakukan pada bulan Januari - Mei 2015.

\subsection{Metode Penelitian}

Penelitian ini dilakukan dengan menggunakan metode penelitian deskriptif dalam bentuk studi kasus untuk memperoleh gambaran yang mendalam dan komprehensif tentang BAZNAS. Metode penelitian menggunakan pendekatan kualitatif dan kuantitatif. Pendekatan kualitatif menggunakan metode deskriptif dilakukan dengan pengamatan langsung dan wawancara untuk memperoleh data, fakta, dan faktor strategis internal dan eksternal organisasi. Pendekatan kuantitatif dilakukan dengan pengisian kuesioner, kemudian hasil kuesioner dibobot dan dinilai. Faktorfaktor strategis yang digunakan diperoleh berdasarkan hasil wawancara dan didukung studi pustaka. 


\subsection{Teknik Pengolahan Data}

Pengambilan data dilakukan dengan menggunakan teknik pemilihan responden berdasarkan purposive sampling melalui pendekatan kepakaran para responden. Teknik ini mempertimbangkan bahwa semua responden dianggap memiliki kompetensi dan kapabilitas yang relevan dan sama untuk memberikan masukan dalam perumusan strategi penghimpunan dana zakat bagi BAZNAS terkait Inpres No.3/2014.

Pengumpulan data dan informasi dilakukan dengan beberapa teknik berikut ini :

1. Wawancara dan kuesioner digunakan untuk menggali informasi terkait dengan tanggung jawab baru BAZNAS seperti yang disebutkan dalam Inpres No.3/2014, serta analisis faktor internal dan eksternal organisasi. Alat bantu yang digunakan berupa kuesioner yang dibuat sesuai alat analisis yang digunakan.

2. Studi kepustakaan digunakan untuk melengkapi data dari berbagai sumber yang memperkuat data hasil penelitian.

Data yang telah terkumpul selanjutnya dianalisis untuk melakukan formulasi strategi penghimpunan zakat bagi BAZNAS. Tahapan dalam pengolahan dan analisis data dijelaskan sebagai berikut :

\subsubsection{Evaluasi Faktor Eksternal (External Factor Evaluation)}

Evaluasi faktor eksternal (EFE) digunakan untuk mengidentifikasi dan mengevaluasi faktor-faktor strategis eksternal yang mempengaruhi organisasi atau perusahaan, baik berupa peluang dan ancaman. Faktor-faktor peluang dan ancaman yang telah diidentifikasi selanjutnya akan dievaluasi dengan menggunakan matriks EFE. Hasil analisis matriks EFE ini akan menggambarkan respon perusahaan terhadap peluang dan ancaman yang ada. Menurut David (2011), tahapan matriks EFE dapat dijelaskan sebagai berikut :

1. Mendaftar faktor-faktor strategis yang telah diidentifikasi sebelumnya, meliputi faktor peluang dan ancaman.

2. Melakukan pembobotan untuk setiap faktor strategis eksternal dengan skala mulai dari 0,0 (tidak penting) sampai 1,0 (sangat penting). Total seluruh bobot dari faktor-faktor strategis tersebut harus sama dengan 1,0.

3. Memberikan peringkat antara 1 sampai 4 pada setiap faktor strategis eksternal tersebut, dimana $4=$ jika respon sangat baik, $3=$ jika respon di atas rata-rata, 2 = jika respon rata-rata, $1=$ jika respon dibawah rata-rata.

Peringkat tersebut menunjukkan seberapa efektif strategi perusahaan yang ada saat ini merespon faktor-faktor strategis eksternal tersebut, sehingga nilainya didasarkan pada kondisi perusahaan.

4. Mengalikan bobot masing-masing faktor dengan peringkat pada tiap faktor untuk memperoleh skor terbobot (weighted score).

5. Menjumlah semua skor terbobot pada setiap faktor untuk mendapatkan skor terbobot total (total weighted score). Total skor 4,0 mengindikasikan bahwa perusahaan merespon peluang yang ada dengan cara yang luar biasa dan menghindari ancaman-ancaman yang ada di industrinya. Total skor 1,0 
mengindikasikan bahwa strategi-strategi perusahaan tidak memanfaatkan peluang-peluang atau tidak menghindari ancaman-ancaman eksternal.

\subsubsection{Evaluasi Faktor Internal (Internal Factor Evaluation)}

Evaluasi faktor internal digunakan untuk mengetahui faktor-faktor internal organisasi atau perusahaan yang berkaitan dengan kekuatan dan kelemahan perusahaan yang dianggap penting (David, 2011). Pada prinsipnya tahapan pada matriks IFE adalah sama dengan matriks EFE. Hasil yang didapat dari kedua matriks tersebut kemudian digabungkan untuk membentuk Matriks InternalEksternal untuk melihat posisi organisasi agar lebih mudah merumuskan strategi yang paling efektif.

\subsubsection{Analisis Matirks SWOT}

Matriks SWOT merupakan alat analisis yang penting untuk membantu perusahaan mengembangkan empat tipe strategi. Keempat strategi yang dimaksud adalah strategi SO (Strength - Opportunity), strategi WO (Weakness - Opportunity), strategi ST (Strength - Threat) dan strategi WT (Weakness - Threat). Konsep perumusan strategi alternatif dengan menggunakan matriks SWOT diperlihatkan pada Gambar 1.

\begin{tabular}{|c|c|c|}
\hline Pembagian Faktor & $\begin{array}{c}\text { Strengths }(\mathrm{S}) \\
\text { Faktor kekuatan internal } \\
\end{array}$ & $\begin{array}{c}\text { Weakness }(\mathrm{W}) \\
\text { Faktor kelemahan internal }\end{array}$ \\
\hline Opport & Strategi S-O & Strategi W-O \\
\hline $\begin{array}{l}\text { Peluang eksternal yang } \\
\text { ada }\end{array}$ & $\begin{array}{l}\text { Ciptakan strategi yang } \\
\text { menggunakan kekuatan } \\
\text { dengan memanfaatkan } \\
\text { peluang }\end{array}$ & $\begin{array}{l}\text { Ciptakan strategi yang } \\
\text { meminimalkan } \\
\text { kelemahan dengan } \\
\text { memanfaatkan peluang }\end{array}$ \\
\hline \begin{tabular}{l}
\multicolumn{1}{c}{ Threats $(\mathrm{T})$} \\
Ancaman eksternal yang \\
ada
\end{tabular} & \begin{tabular}{lr}
\multicolumn{2}{c}{ Strategi S-T } \\
Ciptakan strategi yang \\
menggunakan kekuatan \\
dengan r mengatasai \\
ancaman
\end{tabular} & \begin{tabular}{l}
\multicolumn{2}{c}{ Strategi W-T } \\
Ciptakan strategi yang \\
meminimalkan \\
kelemahan dengan \\
menghindari ancaman
\end{tabular} \\
\hline
\end{tabular}

Sumber : David (2011)

\section{Gambar 1 Ilustrasi matriks SWOT}

\section{Gambaran Umum Organisasi}

\subsection{Profil BAZNAS}

Badan Amil Zakat Nasional (BAZNAS) dibentuk oleh pemerintah pada tanggal 17 Januari 2001 berdasarkan Keputusan Presiden RI No. 8 tahun 2001. BAZNAS merupakan badan resmi dan satu-satunya yang memiliki tugas dan fungsi menghimpun dan menyalurkan zakat, infaq, dan sedekah (ZIS) pada tingkat nasional.

Lahirnya Undang-Undang Nomor 23 Tahun 2011 tentang Pengelolaan Zakat semakin mengukuhkan peran BAZNAS sebagai lembaga yang berwenang melakukan pengelolaan zakat secara nasional. Dalam UU tersebut, BAZNAS dinyatakan sebagai lembaga pemerintah nonstruktural yang bersifat mandiri dan 
bertanggung jawab kepada Presiden melalui Menteri Agama. Sebagai lembaga amil zakat BAZNAS melakukan fungsi perencanaan, pelaksanaan, pengendalian, pelaporan dan pertanggungjawaban atas pengumpulan, pendistribusian dan pendayagunaan zakat.

Landasan syariat berdirinya BAZNAS adalah ayat-ayat Al-Qur'an berikut ini :

"Ambillah zakat dari sebagian harta mereka, dengan zakat itu kamu membersihkan dan mensucikan mereka dan mendoalah untuk mereka. Sesungguhnya doa kamu itu (menjadi) ketentraman jiwa bagi mereka. Dan Allah Maha Mendengar lagi Maha Mengetahui”. QS At-Taubah ayat 103.

Selain dari ayat-ayat diatas terdapat juga hadist dimana Rasul bersabda :

"Beritakan kepada meraka bahwa Allah telah mewajibkan atas mereka shodaqoh (zakat) dari harta mereka yang diambil dari orang-orang kaya dari mereka dan diberikan kepada orang-orang fakir dari mereka" (HR Bukhari). ${ }^{2}$

BAZNAS memiliki visi yang kuat dan tajam bagi arah pengembangannya, yaitu : Menjadi Badan Zakat Nasional yang Amanah, Transparan, dan Profesional". Adapun misi BAZNAS adalah :

1. Meningkatkan kesadaran umat untuk berzakat melalui amil zakat.

2. Meningkatkan penghimpunan dan pendayagunaan zakat nasional sesuai dengan ketentuan syariah dan prinsip manajemen modern.

3. Menumbuhkembangkan pengelola/amil zakat yang amanah, transparan, profesional dan terintegrasi.

4. Mewujudkan pusat data zakat nasional.

5. Memaksimalkan peran zakat dalam menanggulangi kemiskinan di Indonesia melalui sinergi dan koordinasi dengan lembaga terkait.

Berbagai penghargaan telah diterima oleh BAZNAS diantaranya pada tahun 2008 BAZNAS memperoleh predikat Laporan Keuangan Terbaik untuk Lambaga Non Departemen versi Kementrian Keuangan Republik Indonesia. Pada tahun 2009 juga BAZNAS mendapatkan penghargaan The Best Quality Management dari Karim Business Consulting. Kemudian pada tahun 2011 BAZNAS memperoleh penghargaan The Best in Transparancy Management dan The Best Innovative Programme dalam IMZ Award. Sejak tahun 2011 hingga kini pula laporan keuangan BAZNAS telah diaudit oleh akuntan publik dengan opini Wajar Tanpa Pengecualian (WTP), dan sejak tahun 2009 sampai dengan saat ini BAZNAS memperoleh sertifikat ISO 9001-2008.

\subsection{Struktur Organisasi}

Struktur organisasi BAZNAS secara garis besar terdiri dari 2 kelompok susunan kepengurusan, yaitu pengurus BAZNAS dan amil BAZNAS. Pengurus BAZNAS terdiri dari 3 kelompok yaitu Dewan Pertimbangan, Badan Pelaksana dan Komisi Pengawas. Kelompok Badan Pelaksana kemudian dipecah lagi menjadi beberapa

${ }^{2}$ HR. Bukhari, Kitab Zakat 3:261 no.1395 dari hadts Ibnu Abbas RA. 
divisi utama BAZNAS dimana divisi-divisi ini yang disebut sebagai amil BAZNAS.

Amil BAZNAS terdiri dari Direktur Pelaksana yang saat ini dijabat oleh Bapak Teten Kustiawan, SE. Ak yang bertanggung jawab atas 5 divisi utama yaitu; 1) Divisi Penghimpunan, 2) Divisi Pendistribusian dan Pendayagunaan, 3) Divisi Keuangan, HRD \& IT, 4) Divisi Corsec, Legal dan GAF, serta 5) Divisi Perencanaan dan Pengembangan. Seluruh kinerja dari semua divisi dan ketua pelaksana kemudian akan dievaluasii oleh divisi Satuan Audit Internal.

\subsection{Program Penghimpunan Zakat}

Sesuai UU No.23 tahun 2011 BAZNAS mengumpulkan zakat, infak, sedekah dan dana sosial keagamaan lainnya. Dalam pengumpulan dana BAZNAS melakukan sosialisasi zakat ke berbagai kalangan melalui berbagai sarana baik langsung ataupun tidak langsung. Penerimaan zakat oleh BAZNAS dilakukan melalui konter, e-banking, jemput zakat dan payroll system.

Secara garis besar BAZNAS memiliki 2 jenis pendekatan dalam penghimpunan zakat, yaitu Penghimpunan Badan dan Penghimpunan Individu. Penghimpunan Badan ditujukan untuk pengumpulan zakat di lingkungan korporasi swasta, BUMN, lembaga negara dan juga kementrian, sedangkan Penghimpunan Individu merupakan pendekatan penghimpunan terhadap individu dan UMKM. Secara sifat penghimpunan badan bersifat mengikat dan kolektif sefangkan penghimpunan individu memiliki sifat sebaliknya yaitu tidak mengikat dan individual. Dari segi jumlah penghimpunan badan menghimpun dalam jumlah besar melalui sistem layanan yang terintegrasi sedangkan penghimpunan individu melayani penghimpunan dalam jumlah yang relatif kecil dengan sifat layanan yang customized. Segmen market penghimpunan badan juga lebih homogen dibandingkan dengan penghimpunan individu yang memiliki segmen market yang heterogen.

Penghimpunan Badan memiliki 3 jenis produk yaitu; 1) Zakat Badan yang terdiri dari zakat perniagaan dan zakat perusahaan, 2) Zakat Profesi yang bertujuan untuk penghimpuanan dana ZIS para pegawai melalui Unit Pengumpul Zakat (UPZ) atau pun melalui sistem payroll, 3) Sinergi program BASNAZ dengan CSR berbagai Bank Syariah nasional yang menghasilkan program-program pemberdayaan seperti Zakat Community Development, Rumah Sehat BASNAZ, Rumah Cerdas Anak Bangsa, Rumah Makmur BAZNAS, dan juga Tanggap Darurat Bencana.

Di sisi lain pendekatan Penghimpunan Individu memiliki lebih banyak produk dibandingkan dengan program penghimpunan badan. Program-program yang menjadi bagian dari Penghimpunan Individu adalah sebagai berikut :

1. Bank \& Insurance Linkage. Program ini bertujuan untuk menghimpun dana ZIS nasabah dan memberikan kemudahan pembayaran ZIS melalui Bank. Kerjasama ini melibatkan beberapa bank syariah nasional.

2. Retail Store. Program ini bertujuan untuk menghimpun dana ZIS pelanggan memlaui pembukaan zakah payment point. 
3. A Funding Website. Program ini sekaligus meningkatkan fungsi layanan pada Web BAZNAS yang menjadikan situs tersebut sebagai salah satu channel penghimpunan dana ZIS.

4. Direct Selling. Program ini bertujuan untuk meningkatkan jaringan penghimpunan BAZNAS dengan meningkatkan jumlah muzakki prima individu.

5. Celular Funding. Program ini bertujuan untuk menghimpun dana ZIS via telepon selular melalui produk-produk yang ditawarkan.

6. Social Media. Program ini bertujuan untuk meningkatkan interaksi dan kesadaran masyarakat akan pentingnya zakat. Melalui social media BAZNAS memasarkan layanan ZIS dan program-program penyaluran yang dimiliki.

7. Overseas Funding. Program ini bertujuan untuk menghimpun dana ZIS di luar negeri sekaligus untuk membuka layanan ZIS ritel untuk luar negri. Kerjasama yang telah terjalin dalam rangka melaksanakan program ini adalah dengan organisasi-organisasi yang berbasis di luar negeri.

8. Advertising. Program ini bertujuan untuk menghimpun dana ZIS ritel dari masyarakat secara umum melalui pemasaran BAZNAS berikut layanannya.

Sebagai penyempurna dari program-program penghimpunan yang ada BAZNAS menerbitkan NPWZ (Nomor Pokok Wajib Zakat) sebagai bagian dari manajemen database muzakki. BAZNAS juga mengeluarkan Bukti Setor Zakat (BSZ) yang dapat dijadikan bukti zakat sebagai pengurang penghasilan kena pajak. Dan sebagai bentuk pertanggungjawaban kepada para muzaki BAZNAS memberikan laporan keuangan rutin dalam berbagai bentuk seperti Laporan Donasi, Majalah Zakat, Notifikasi sms dan email, serta fasilitas internet berupa aplikasi muzakki corner.

\subsection{Program Penyaluran Zakat}

BAZNAS menyalurkan zakat kepada delapan golongan (ashnaf) yang berhak menerima (mustahik) dengan program-progam yang inovarif dan efektif dalam rangka mewujudkan pemuliaan para mustahik dan mengantarkannya menjadi muzaki. Penyaluran yang dilakukan oleh BAZNAS mencakup seluruh wilayah nusantara. Penyaluran zakat oleh BAZNAS terdiri dari 2 jenis yaitu dalam bentuk santunan atau yang bersifat konsumtif, dan dalam bentuk pemberdayaan atau yang bersifat produktif.

Program BAZNAS yang bersifat produktif (pemberdayaan) antara lain :

1. Zakat Community Development (ZCD). Program ini merupakan program pengembangan komunitas dengan mengintegrasikan aspek sosial dan aspek ekonomi secara komprehentsif yang pendanaan utamanya bersumber dari zakat, infak dan sedekah sehingga terwujud masyarakat sejahtera dan mandiri.

2. Rumah Makmur BAZNAS merupakan program yang bergerak di bidang ekonomi melalui pemberian modal kerja dengan sistem pendampingan dan pembinaan. Pelaksanaan program ini fokus di wilayah perkotaan dengan pendanaan untuk peningkatan kapasitas modal kerja dan pendampingan. 
3. Rumah Cerdas Anak Bangsa (RCAB). Program ini merupakan program pendanaan dan bimbingan siswa dan mahasiswa dalam bidang pendidikan dan pelatihan.

4. Rumah Sehat BAZNAS. Program ini merupakan program pelayanan kesehatan yang komprehensif meliputi preventif, promotif, kuratif dan rehabilitatif yang dikhususkan bagi masyarakat miskin secara gratis dengan menggunakan sistem membership.

5. Rumah Da'wah BAZNAS. Program ini merupakan program penyaluran zakat yang ditujukan kepada mualaf, kaderisasi ulama mutafaqqih fiddin yang menjadi pelopor pembangunan masyarakat, dan berbagai kegiatan dakwah untuk masyarakat miskin dan daerah terpencil dan terluar.

Sementara Program BAZNAS yang bersifat konsumtif berupa santunan hanya terdiri dari 2 produk atau program. Yang pertama adalah Konter Layanan Mustahik dan yang kedua program Tanggap Darurat Bencana.

\subsection{Instruksi Presiden No.3 Tahun 2014}

Pada tanggal 23 April 2014 Presiden Susilo Bambang Yudhoyono menandatangani Instruksi Presiden Republik Indonesia tentang Optimalisasi Pengumpulan Zakat di Kementerian/Lembaga, Sekretariat Jenderal Lembaga Negara, Sekretariat Jenderal Komisi Negara, Pemerintah Daerah, Badan Usaha Milik Negara, dan Badan Usaha Milik Daerah melalui Badan Amil Zakat Nasional.

Dalam Inpres No 3 Tahun 2014 tersebut Presiden menginstruksikan kepada : 1) Para Menteri; 2) Jaksa Agung; 3) Panglima Tentara Nasional Indonesia; 4) Kepala Kepolisian Republik Indonesia; 5) Para Pimpinan Lembaga Pemerintah NonKementrian; 6) Para Sekertaris Jenderal Lembaga Negara; 7) Para Sekretaris Jenderal Komisi Negara; 8) Gubernur; 9) Bupati/Walikota; dan 10) Ketua Badan Amil Zakat Nasional, untuk melakukan koordinasi sesuai tugas dan fungsi masingmasing dengan BAZNAS dalam pengumpulan zakat dengan cara melakukan sosialisasi dan penyebarluasan informasi mengenai zakat kepada seluruh pegawai/karyawan yang beragama Islam serta mendorong memfasilitasi pegawai/karyawan di lingkungan instansi masing-masing untuk membayar zakat melalui BAZNAS.

Khusus kepada Menteri Dalam Negeri agar mendorong gubernur dan bupati/walikota untuk melakukan optimalisasi pengumpulan zakat di satuan kerja/organisasi perangkat daerah dan Badan Usaha Milik Daerah melalui BAZNAS Provinsi dan Kapubaten/Kota. Khusus kepada Menteri Badan Usaha Milik Negara agar mendorong Direksi/Pimpinan Badan Usaha Milik Negara untuk melakukan optimalisasi pengumpulan zakat karyawan dan zakat badan usaha di lingkungan Badan Usaha Milik Negara melalui BAZNAS.

Kepada Ketua BAZNAS diinstruksikan untuk melakukan empat hal, yaitu :

1. Melakukan registrasi muzakki bagi pegawai/karyawan di Kementerian/Lembaga, Sekertariat Jenderal Lembaga Negara, Sekertariat jenderal Komisi Negara, Pemetintah Daerah, BUMN, dan BUMD. 
2. Membuat mekanisme teknis pengumpulan zakat di lingkungan Kementerian/Lembaga, Sekertariat Jenderal Lembaga Negara, Sekertariat jenderal Komisi Negara, Pemetintah Daerah, BUMN, dan BUMD.

3. Melakukan pengumpulan zakat di lingkungan Kementerian/Lembaga, Sekertariat Jenderal Lembaga Negara, Sekertariat jenderal Komisi Negara, Pemetintah Daerah, BUMN, dan BUMD.

4. Menyampaikan laporan hasil pengelolaan zakat di Kementerian/Lembaga, Sekertariat Jenderal Lembaga Negara, Sekertariat jenderal Komisi Negara, Pemetintah Daerah, BUMN, dan BUMD terkait kepada Pimpinan Instansi dengan tembusan kepada Presiden melalui Menteri Agama.

Keberadaan Inpres Zakat harus dimaknai sebagai upaya mendorong intensi peran penyelenggara negara dalam optimalisasi pengelolaan zakat di ranah kebijakan publik. Menindaklanjuti Inpres tersebut BAZNAS melakukan sosialisasi kepada seluruh kementerian dan lembaga tinggi negara perihal optimalisasi zakat di lingkungan kerja masing-masing melalui BAZNAS. Bagi Pegawai Negeri Sipil (PNS) Muslim yang penghasilannya telah mencapai nishab yaitu Rp.3,458,400* akan dipotong zakat sebesar 2,5\%. (*Hasil perhitungan $524 \mathrm{~kg}$ x Rp.6,600. Harga Rp.6,600 berdasarkan harga yang tertuang dalam instruksi presiden nomor 3 tahun 2012 tentang Kebijakan Pengadaan Gabah/Beras dan Penyaluran Beras oleh Pemerintah).

Berdasarkan penelitian yang dilakukan oleh BAZNAS total potensi zakat untuk seluruh kementerian dan lembaga tinggi negara serta pejabat tinggi negara mencapai angka Rp. 582 Miliar (lihat Tabel 3), setara dengan 0,27\% dari total potensi zakat nasional.

Tabel 3 Total Potensi Zakat Kementrian/Lembaga Tinggi Negara

\begin{tabular}{lrrrc}
\hline \multicolumn{1}{c}{ SUMBER POTENSI ZAKAT } & & Potensi Zakat & Muzaki & Presentase \\
\hline $\begin{array}{l}\text { PEJABAT TINGGI NEGARA } \\
\text { EKSEKUTIF }\end{array}$ & $\mathrm{Rp}$ & 3.706 .467 .768 & 796 & $0.64 \%$ \\
$\begin{array}{l}\text { PEJABAT TINGGI NEGARA } \\
\text { YUDIKATIF \& LEGISLATIF }\end{array}$ & $\mathrm{Rp}$ & 2.125 .670 .185 & 1.898 & $0.37 \%$ \\
$\begin{array}{l}\text { KEMENTERIAN } \\
\text { LEMBAGA PEMERINTAH NON }\end{array}$ & $\mathrm{Rp}$ & 513.475 .166 .892 & 453.256 & $88.17 \%$ \\
KEMENTERIAN & $\mathrm{Rp}$ & 63.061 .480 .437 & 53.361 & $10.83 \%$ \\
\hline \multicolumn{1}{c}{ Total } & Rp & $\mathbf{5 8 2 . 3 6 8 . 7 8 5 . 2 8 2}$ & $\mathbf{5 0 9 . 3 1 1}$ & $\mathbf{1 0 0 \%}$ \\
\hline
\end{tabular}

\section{Hasil dan Pembahasan}

\subsection{Analisis Lingkungan Internal}

Analisis lingkungan internal dilakukan untuk mengetahui tingkat kemampuan BAZNAS dalam menjalankan Instruksi Presiden No.3 tahun 2014 berdasarkan kondisi internal organisasi. Untuk menganalisis lingkungan internal maka perlu diidentifikasi faktor-faktor strategis internal BAZNAS yang terdiri dari faktor kekuatan dan faktor kelemahan. Identifikasi faktor-faktor internal tersebut dilakukan dengan cara wawancara dengan para responden yang berasal dari pihak 
internal maupun eksternal BAZNAS. Hasil dari wawancara tersebut telah ditemukan masing-masing 5 faktor kekuatan dan kelemahan BAZNAS.

Faktor-faktor kekuatan dan kelamahan BAZNAS dijelaskan lebih rinci sebagai berikut :

1. Kekuatan

- Tokoh BAZNAS yang memiliki jaringan ke Kementerian atau Lembaga Tinggi Negara. Adanya tokoh BAZNAS yang disegani sedikit banyak mempermudah proses sosialisasi dan juga follow up karena memiliki koneksi langsung dengan pengambil keputusan di setiap kementerian maupun lembaga.

- Transparansi dan akuntabilitas keuangan BAZNAS. Faktor ini juga merupakan salah satu dari yang terpenting sebagai nilai jual BAZNAS dalam menawarkan jasa pengelolaan zakat.

- Program-program pemberdayaan unggulan. Penyaluran zakat yang dilakukan oleh BAZNAS mencakup skala nasional, dibandingkan lembaga-lembaga zakat lain yang belum mampu menyentuh hingga ke seluruh pelosok negeri.

- Model Penghimpunan dana zakat BAZNAS. BAZNAS merupakan satu-satunya badan zakat yang mengeluarkan NPWZ (nomor pokok wajib zakat) bagi para muzakki yang menyalurkan zakat di BAZNAS.

- Kerjasama dengan lembaga-lembaga di dalam maupun luar negeri. Kerjasama BAZNAS dengan banyak lembaga perbankan serta lembaga kemanusiaan memberikan kemudahan-kemudahan bagi para muzakki.

2. Kelemahan

- Sistem jaringan berbasis IT di BAZNAS daerah. Hal ini menjadi kelemahan karena dapat menghambat proses komunikasi, implementasi Inpres dan juga evaluasi pengelolaan dana zakat disebabkan sistem yang tidak online dengan pusat.

- Jumlah SDM terbatas. Total pegawai BAZNAS di kantor pusat kurang lebih hanya sekitar 80 orang. Jumlah tersebut terbilang kecil bahkan untuk mengelola dana zakat di pusat, terlebih lagi untuk skala nasional.

- Besaran APBN yang diterima BAZNAS. Tiap tahunnya BAZNAS menerima bantuan dana dari pemerintah melalui Kementerian Agama hanya sebesar 3 Milyar Rupiah. Nilai tersebut digunakan oleh BAZNAS untuk seluruh kepentingan operasional selama satu tahun.

- Rangkap jabatan di BAZNAS pusat. Dengan jumlah SDM terbatas dan begitu banyaknya program yang dimiliki secara tidak langsung memaksa sebagian pengurus untuk merangkap jabatan. 
- Pemahaman tentang zakat yang belum merata di kalangan amil. Banyaknya amil yang bekerja di BAZNAS dari latar belakang yang berbeda membuat pemahaman tentang zakat di kalangan amil beragam.

\subsection{Matriks Evaluasi Faktor Internal (IFE Matrix)}

Matriks Evaluasi Faktor Internal (IFE Matrix) digunakan untuk mengetahui seberapa besar respon BAZNAS dalam memanfaatkan kekuatan dan mengatasi kelemahan yang dimiliki dalam menjalankan Inpres No.3/2014. IFE Matrix dibuat dengan menggunakan input dari faktor-faktor strategis yang mencakup kekuatan dan kelemahan organisasi seperti yang telah dijelaskan pada subbab sebelumnya. Faktor-faktor kekuatan dan kelemahan tersebut kemudian diberikan pembobotan yang menunjukkan tingkat kepentingan relatif dari masing-masing faktor tersebut yang menjadi kunci sukses dalam menjalankan Inpres No.3 tahun 2014.

Faktor yang dipertimbangkan memiliki tingkat kepentingan relatif paling tinggi diberikan bobot paling tinggi, sedangkan faktor yang dipertimbangkan memiliki tingkat kepentingan relatif paling rendah diberikan bobot paling rendah. Setelah diberikan pembobotan, masing-masing faktor strategis tersebut kemudian diberikan nilai yang menunjukkan peringkat dari setiap faktor yang menjadi kekuatan atau kelemahan perusahaan. Nilai 4 menunjukkan kekuatan utama sedangkan nilai 1 menunjukkan kelemahan utama.

Bobot dan peringkat dari masing-masing faktor dan perhitungan skor terbobot total dari analisis faktor strategis internal BAZNAS dituangkan dalam Matriks Evaluasi Faktor Internal seperti diperlihatkan pada Tabel 4.

Tabel 4 Matriks Evaluasi Faktor Internal BAZNAS

\begin{tabular}{|c|c|c|c|}
\hline KEKUATAN & Bobot & Peringkat & Score \\
\hline $\begin{array}{l}\text { Tokoh BAZNAS yang memiliki jaringan } \\
\text { ke Kementrian / Lembaga Tinggi Negara }\end{array}$ & 0,095 & 4 & 0,380 \\
\hline $\begin{array}{l}\text { Transparansi dan akuntabilitas keuangan } \\
\text { BAZNAS }\end{array}$ & 0,125 & 4 & 0,500 \\
\hline $\begin{array}{l}\text { Program-program } \quad \text { pemberdayaan } \\
\text { unggulan }\end{array}$ & 0,128 & 4 & 0,510 \\
\hline $\begin{array}{l}\text { Model penghimpunan dana zakat } \\
\text { BAZNAS }\end{array}$ & 0,083 & 3 & 0,248 \\
\hline $\begin{array}{l}\text { Kerjasama Lembaga (perbankan, lembaga } \\
\text { dalam \& luar negeri) }\end{array}$ & 0,070 & 3 & 0,210 \\
\hline
\end{tabular}

\begin{tabular}{llll}
\hline Sistem Jaringan berbasis IT di BAZNAS & & & \\
daerah & 0,119 & 1 & 0,119 \\
Jumlah SDM terbatas & 0,091 & 1 & 0,091 \\
Besaran APBN yang diterima BAZNAS & 0,094 & 2 & 0,188
\end{tabular}




\begin{tabular}{rrrr}
$\begin{array}{l}\text { Rangkap jabatan di BAZNAS Pusat } \\
\text { Pemahaman tentang zakat belum merata } \\
\text { di kalangan Amil }\end{array}$ & 0,075 & 1 & 0,075 \\
\hline TOTAL & 0,122 & 1 & 0,122 \\
\hline
\end{tabular}

Perhitungan antara bobot dan peringkat dari masing-masing faktor yang ditampilkan pada Tabel 18 menghasilkan skor terbobot dari masing-masing faktor dan skor terbobot total yang dapat menunjukkan kondisi internal BAZNAS terhadap implementasi Inpres. Skor terbobotal total dari Matriks Evaluasi Faktor Internal untuk BAZNAS adalah 2,441. Skor terbobot tersebut berada sedikit di bawah rata-rata 2,5. Hal ini menunjukkan bahwa secara internal, kondisi BAZNAS masih sedikit di bawah rata-rata dalam rangka melakukan optimalisasi penghimpunan dana zakat di lingkungan kementerian/lembaga..

Kondisi internal organisasi perlu diketahui untuk menjadi pedoman perusahaan dalam merumuskan strategi-strategi alternatif perusahaan dalam menjalankan Inpres No.3/2014 dengan memanfaatkan kekuatan dan mengatasi kelemahan yang dimiliki. Dua kekuatan utama BAZNAS yang paling penting untuk diperhatikan dalam penyusunan strategi implementasi Inpres adalah (1) program-program pemberdayaan unggulan dengan bobot 0,128 dan (2) transparansi dan akuntabilitas keuangan BAZNAS dengan bobot 0,125. Sedangkan dua kelemahan utama BAZNAS yang paling penting untuk diperhatikan yaitu (1) pemahaman tentang zakat yang belum merata di kalangan amil dengan bobot 0,122 dan (2) jaringan berbasis IT di BAZNAS daerah dengan bobot 0,119.

\subsection{Analisis Lingkungan Eksternal}

Analisis lingkungan eksternal dilakukan untuk mengetahui tingkat kemampuan BAZNAS dalam menjalankan Instruksi Presiden No.3 tahun 2014 berdasarkan kondisi eksternal organisasi. Untuk menganalisis lingkungan eksternal maka perlu diidentifikasi faktor-faktor strategis eksternal BAZNAS yang terdiri dari faktor peluang dan faktor hambatan. Identifikasi faktor-faktor eksternal tersebut dilakukan dengan cara wawancara dengan para responden yang berasal dari pihak internal maupun eksternal BAZNAS. Hasil dari wawancara tersebut telah ditemukan masing-masing 5 faktor peluang dan hambatan BAZNAS dalam menjalankan Inpres No.3/2014.

Masing-masing faktor peluang dan hambatan BAZNAS dalam menjalankan Inpres No.3 tahun 2014 dijelaskan lebih rinci sebagai berikut :

1. Peluang

- Pergantian kabinet pemerintah. Hadirnya kepemerintahan baru di bawah pimpinan Presiden Joko Widodo diharapkan bisa membawa angin segar kepada optimalisasi zakat oleh BAZNAS terkait Inpres No.3/2014. 
- Pertumbuhan kelas menengah penduduk Muslim Indonesia. Dengan potensi pasar yang begitu besar, kelas menengah Muslim Indonesia tidak bisa diabaikan begitu saja oleh para pemasar dari berbagai industri, termasuk industri zakat.

- Hubungan baik dengan Lembaga Amil Zakat (LAZ) lain. Hubungan yang sudah terjalin dengan para LAZ merupakan peluang yang baik untuk menjadikan mereka sebagai perpanjangan tangan BAZNAS dalam mensosialisasikan Inpres No.3/2014.

- Tokoh masyarakat yang pro pembayaran zakat via amil zakat. Peran tokoh agama / masyarakat menjadi sangat penting ketika mereka mampu mengajak masayarakat untuk membayar zakat melalui amil.

- Peningkatan iklim syariah di bidang ekonomi, budaya, hiburan, dll. Berkembangnya produk-produk Islami di Indonesia seperti kosmetik halal, Salon Muslimah, hotel syariah, dll memberikan peluang bagi BAZNAS untuk turut mensosialisasikan pentingnya peran zakat di tengah masyarakat.

2. Hambatan

- Birokrasi di lingkungan kementerian/lembaga. Birokrasi yang berbelit dan struktur organisasi yang memiliki banyak hirarki menyulitkan BAZNAS untuk melakukan pertemuan dengan pihak pemegang keputusan di lingkungan kementrian dan lembaga.

- Sistem jaringan IT yang belum merata di kementerian/lembaga. Faktor ini juga akan menghambat kinerja BAZNAS dalam menjalankan Inpres tersebut dikarenakan BAZNAS menawarkan kerjasama pemungutan zakat melalui sistem payroll.

- Pemahaman tentang zakat yang masih rendah di kalangan masyarakat umum. Kurangnya informasi seputar zakat dan pengelolaan zakat di tengah masyarakat membuat tingkat pemahaman zakat masyarakat Indonesia cenderung rendah dan beragam.

- Tingkat kepercayaan masyarakat yang rendah terhadap lembaga pemerintah. Sebagai lembaga pemerintah, hal ini menyulitkan karena memberikan image yang kurang baik terhadap BAZNAS di mata umum.

- Muzaki di lingkungan kementerian/lembaga mempunyai jaringan sendiri untuk menyalurkan zakatnya. Hal ini dikarenakan masifnya promosi LAZ lain dan kurangnya sosialisasi program unggulan BAZNAS. 


\subsection{Matriks Evaluasi Faktor Eksternal (EFE Matrix)}

Matriks Evaluasi Faktor Eksternal (EFE Matrix) digunakan untuk mengukur tingkat respon BAZNAS dalam memanfaatkan peluang dan mengatasi hambatan yang dihadapi dalam menjalankan Inpres No.3/2014. EFE Matrix dibuat dengan menggunakan input dari faktor-faktor strategis yang mencakup peluang dan hambatan organisasi seperti yang telah dijelaskan pada subbab sebelumnya. Faktorfaktor peluang dan hambatan tersebut kemudian diberikan pembobotan yang menunjukkan tingkat kepentingan relatif dari masing-masing faktor tersebut yang menjadi kunci sukses dalam menjalankan Inpres No.3 tahun 2014.

Faktor-faktor tersebut juga diberikan peringkat yang menunjukkan seberapa efektif strategi perusahaan yang ada saat ini merespon faktor-faktor tersebut. Bobot dan peringkat tersebut akan mempengaruhi hasil skor terbobot total yang menunjukkan tingkat respon perusahaan, posisi perusahaan dan strategi-strategi alternatif yang harus dirumuskan. Bobot dan peringkat dari masing-masing faktor dan perhitungan skor terbobot total dari analisis faktor strategis eksternal BAZNAS dituangkan dalam Matriks Evaluasi Faktor Eksternal seperti diperlihatkan pada Tabel 5.

Perhitungan antara bobot dan peringkat dari masing-masing faktor yang ditampilkan pada Tabel 5 menghasilkan skor terbobot dari masing-masing faktor dan skor terbobot total yang dapat menunjukkan kondisi eksternal perusahaan terhadap implementasi Inpres. Skor terbobot total dari Matriks Evaluasi Faktor Eksternal untuk BAZNAS adalah 2,505. Skor terbobot tersebut berada tepat di rata-rata 2,5. Hal ini menunjukkan bahwa secara eksternal kondisi BAZNAS sudah cukup baik dalam merespon peluang dan hambatan yang ada dalam menjalankan Inpres, namun masih terdapat ruang untuk perbaikan dalam memberikan respon yang lebih optimal. Hal ini kemudian mengarahkan kepada perumusan strategistrategi alternatif bagi BAZNAS yang dapat mengoptimalkan peluang dan mengatasi hambatan yang ada.

Dari analisis faktor eksternal tersebut juga dapat diperlihatkan dua faktor peluang yang paling penting yaitu (1) tokoh masyarakat yang pro pembayaran zakat via amil zakat dengan bobot 0,123 dan (2) pertumbuhan kelas menengah penduduk Muslim Indonesia dengan bobot 0,118 . Sedangkan dua hambatan yang paling penting adalah (1) pemahaman zakat yang masih rendah di kalangan masyarakat umum dengan bobot 0,123 dan (2) tingkat kepercayaan masyarakat yang rendah terhadap lembaga pemerintah dengan bobot yang sama besar yaitu 0,123 . 
Tabel 5 Matriks Evaluasi Faktor Eksternal BAZNAS

\begin{tabular}{|c|c|c|c|}
\hline PELUANG & Bobot & Peringkat & Score \\
\hline Pergantian kabinet pemerintah & 0,068 & 1 & 0,068 \\
\hline Pertumbuhan kelas menengah penduduk Muslim & & & \\
\hline Indonesia & 0,118 & 3 & 0,353 \\
\hline $\begin{array}{l}\text { Hubungan baik dengan Lembaga Amil Zakat lain } \\
\text { Tokoh masyarakat yang Pro pembayaran zakat via }\end{array}$ & 0,080 & 2 & 0,160 \\
\hline Amil Zakat & 0,123 & 3 & 0,368 \\
\hline $\begin{array}{l}\text { Peningkatan iklim syariah di bidang ekonomi, } \\
\text { budaya, hiburan, dll }\end{array}$ & 0,113 & 3 & 0,338 \\
\hline \multicolumn{4}{|l|}{ HAMBATAN } \\
\hline $\begin{array}{l}\text { Birokrasi di Lingkungan Kementrian/Lembaga } \\
\text { Negara }\end{array}$ & 0,088 & 2 & 0,175 \\
\hline $\begin{array}{l}\text { Sistem jaringan IT yang belum merata di } \\
\text { Kementrian/Lembaga negara } \\
\text { Pemahaman tentang zakat yang masih rendah di }\end{array}$ & 0,070 & 2 & 0,140 \\
\hline kalangan masyarakat umum & 0,123 & 2 & 0,245 \\
\hline $\begin{array}{l}\text { Tingkat kepercayaan masyarakat yang rendah } \\
\text { terhadap lembaga pemerintah }\end{array}$ & 0,123 & 3 & 0,368 \\
\hline $\begin{array}{l}\text { Muzakki di Lingkungan Kementrian/Lembaga } \\
\text { punya jaringan zakat sendiri }\end{array}$ & 0,098 & 3 & 0,293 \\
\hline TOTAL & 1,000 & & 2,505 \\
\hline
\end{tabular}

\subsection{Analisis Matriks Internal - Eksternal}

Matriks Internal - Eksternal (Matriks IE) menggambarkan posisi perusahaan ke dalam matriks yang terdiri atas sembilan sel yang memiliki tiga implikasi strategi yang berbeda. Matriks IE dibuat dari input Matriks IFE dan matriks EFE. Pada Matriks IFE, Badan Amil Zakat Nasional memiliki skor terbobot total 2,441 sedangkan pada matriks EFE BAZNAS memiliki skor terbobot total 2,505.

Posisi organisasi yang berada di sel V paling baik dikendalikan dengan strategi menjaga dan mempertahankan (David, 2011). Strategi yang paling umum dilakukan adalah dengan penetrasi pasar dan pengembangan produk. Posisi BAZNAS adalah posisi rata-rata, sehingga pada posisi tersebut BAZNAS masih cukup potensial untuk dikembangkan, namun begitu juga tidak dianjurkan untuk mengembangkan strategi yang terlalu agresif seperti misalnya strategi integrasi atau akuisisi. Pada posisi ini perusahaan hanya perlu fokus menjaga, mempertahankan dan meningkatkan kinerjanya.

\subsection{Analisis SWOT}

Analisis SWOT (Strength-Weakness-Opportunity-Threat) dilakukan untuk mendapatkan strategi-strategi alternatif perusahaan yang akan dikembangkan dengan melihat input dari analisis faktor internal, faktor eksternal dan juga mengacu pada hasil analisis Matriks Internal-Eksternal. Analisis SWOT dilakukan 
dengan menggunakan Matriks SWOT yang dapat menggambarkan secara jelas bagaimana peluang dan ancaman eksternal yang dihadapi dapat disesuaikan dengan kekuatan dan kelemahan internal yang dimiliki. Matriks SWOT yang dibuat juga mengacu pada hasil analisis matriks IE, dimana pada matriks tersebut BAZNAS berada pada posisi Sel V atau rata-rata sehingga direkomendasikan BAZNAS paling baik dikendalikan dengan strategi yang moderat yaitu menjaga dan mempertahankan. Analisis perumusan strategi SO, WO, ST dan WT ditunjukkan pada Gambar 2.

\begin{tabular}{|c|c|c|}
\hline & $S$ & W \\
\hline 0 & $\begin{array}{l}\text { Strategi S-0: } \\
\text { 1. Pemanfaatan tokoh BAZZAS untuk perluasan jaringan di lingkungann kementrian \& lembaga } \\
\text { 2.Penguatan aliansi untuk memberikan kemudahan transaks bagg karyawan }\end{array}$ & $\begin{array}{l}\text { Strategi W-0 } \\
\text { 1. Penguatan kapasitas SDM } \\
\text { 2. Memperbaiki sistem IT di daerah untuk meningkatkan pelayanan di daerah } \\
\text { 3. Melakukan pendekatan dengan kabinet baru terkatitAPBN }\end{array}$ \\
\hline $\mathrm{T}$ & 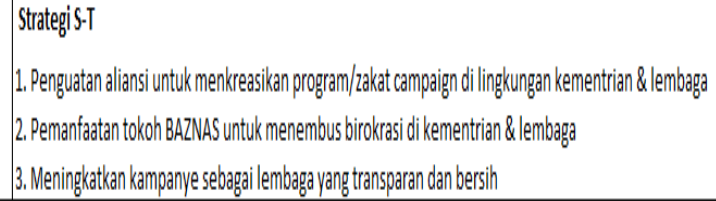 & $\begin{array}{l}\text { Strategi W-T } \\
\text { 1. Penunjukan staf PNS di tiap lembaga untuk menjadi perpanjangan tangan BAZNAS }\end{array}$ \\
\hline
\end{tabular}

\section{Gambar 2 Matriks SWOT}

Matriks SWOT dipergunakan untuk memberikan alternatif-alternatif strategi secara umum untuk BAZNAS dalam menjalankan Inpres No.3 tahun 2014. Perumusan matriks SWOT dihasilkan dari faktor-faktor strategi internal (matriks IFE) dan faktor-faktor strategi eksternal (matriks EFE) yang memperlihatkan posisi dan kondisi organisasi (IE Matriks). Output yang dihasilkan berupa alternstif strategi sebagai berikut :

\section{Strategi S-O (Strengths - Opportunities)}

a. Pemanfaatan peran tokoh BAZNAS untuk perluasan jaringan di lingkungan kementrian kementerian dan lembaga.

b. Penguatan aliansi untuk memberikan kemudahan transaksi bagi para karyawan di kementerian \& lembaga.

\section{Strategi W-O (Weaknesses - Opportunities)}

a. Penguatan kapasitas dan kapabilitas SDM

b. Memperbaiki sistem IT di daerah

c. Melakukan pendekatan dengan kabinet baru terkait APBN.

\section{Strategi S-T (Strengths - Threats)}

a. Penguatan aliansi untuk menkreasikan program / zakat campaign di lingkungan kementerian \& lembaga.

b. Pemanfaatan peran tokoh BAZNAS untuk menembus birokrasi di kementerian \& lembaga.

c. Meningkatkan kampanye sebagai lembaga yang transparan dan bersih. 


\section{Strategi W-T (Weaknesses- Threats)}

a. Melakukan strategi pemungutan dana zakat melalui sistem payroll dimana dana zakat dipotong langsung pada saat penggajian tiap bulannya.

\section{Simpulan dan Saran}

Dari berbagai hasil pembahasan diatas maka dapat diambil kesimpulan bahwa kekuatan utama BAZNAS adalah program-program pemberdayaan unggulan $(0,128)$ dan transparansi serta akuntabilitas keuangan $(0,125)$. Sedangkan kelemahan utama BAZNAS adalah pemahaman tentang zakat yang kurang merata di kalangan amil $(0,122)$ dan jaringan berbasis IT di BAZNAS daerah $(0,119)$. Analisis matriks EFE menunjukkan bahwa peluang utama BAZNAS dalam implementasi inpres no.3/2014 adalah tokoh masyarakat yang pro pembayaran zakat via amil $(0,123)$ dan pertumbuhan kelas menengah muslim Indonesia $(0,118)$. Sedangkan hambatan utama yang dihadapi BAZNAS adalah pemahaman masyarakat tentang zakat yang masih rendah $(0,123)$ dan tingkat kepercayaan masyarakat yang juga rendah terhadap lembaga pemerintah $(0,123)$.

Berdasarkan matriks IE BAZNAS berada pada kuadran V dengan fokus pada strategi penetrasi pasar dan pengembangan produk. Pada posisi ini BAZNAS dianjurkan untuk fokus menjaga, mempertahankan dan meningkatkan kinerjanya. Berdasarkan matriks SWOT maka langkah-langkah strategi alternatif yang dapat dilakukan adalah (1) pemanfaatan tokoh BAZNAS untuk perluasan jaringan dan juga (2) untuk menembus birokrasi di kementerian dan lembaga, (3) penguatan aliansi untuk memberikan kemudahan kepada tiap karyawan dan juga (4) untuk menkreasikan zakat campaign di tiap lembaga. Selain itu BAZNAS juga disarankan (5) untuk meningkatkan kampanye sebagai lembaga yang transparan dan berish, (6) memperbaiki sistem IT di daerah, (7) penguatan kapasitas SDM (8) melakukan pendekatan dengan kabinet baru terkait APBN, dan (9) Melakukan strategi pemungutan dana zakat melalui sistem payroll dimana dana zakat dipotong langsung pada saat penggajian tiap bulannya.

Untuk penelitian selanjutnya diharapkan dapat melakukan penelitian yang lebih mendalam terkait strategi organisasi yang terjadi pada lembaga amil zakat Indonesia dengan mengambil objek yang lebih luas, tidak terikat pada strategi implementasi inpres saja. Variabel yang diperdalam tidak hanya faktor internal dan eksternal saja namun juga dapat menggunakan alat analisis yang lain.

\section{Daftar Pustaka}

Ahmad WMW \& Mohamed S. Classical Jurists' View on the Allocation of Zakat: Is Zakat Investment Allowed?. Middle-East Journal of Scientific Research 12 (2), 195-203 (2012).

Anggorojati, T., Formulasi Strategi Diler Mobil Chevrolet PT. Prima Autoworld Cabang Serpong. [Tesis] Bogor : MB IPB (2014). 
Bakar MHA \& Ghani AHA. Towards Achieving the Quality Life in the Management of Zakat Distribution to the Rightful Recipients (the Poor and Needy). International Journal of Business and Social Science, Vol. 2 (2011).

Bakar NBA \& Rashid HMA. Motivations of Paying Zakat on Income : Evidence from Malaysia. International Journal of Economics and Finance, Vol. 2 (2010).

Beik, I. S., Economic Role of Zakat in Reducing Poverty and Income Inequality. Germany : LAP LAMBERT Academic Publishing (2013).

David, F. R., Strategic Management : Concepts and Cases. 11th Edition. England : Pearson Education Limited (2011).

Hafidhuddin, D., Zakat Dalam Perekonomian Modern. Jakarta : Gema Insani (2002).

Hafidhuddin, D., Nasar, F., Kustiawan, T., Beik, I. S., dan Hakiem, H., Fiqh Zakat Indonesia. Jakarta : Badan Amil Zakat Nasional. (2013).

Ireland, R. D., Hoskisson, R. E., Hitt, M. A., The Management of Strategy: Concepts and Cases. 10th Edition. Canada : South-Western Cengage Learning (2013).

Jamil. Arsitektur Strategik Lembaga Amil Zakat : Dompet Dhuafa Republika. [Tesis] Bogor : MB IPB (2003).

Laela, A., Formulasi Model Pemberdayaan Ekonomi Masyarakat Miskin Melalui Zakat (Studi Kasus Empat OPZ di Kabupaten dan Kota Bogor). [Tesis] Bogor : MB IPB (2010).

Mintarti, N., Beik, I.S., Tanjung, H., Haryono, A. R., Tsani, T., dan Kasirin, U., Indonesia Zakat and Development Report 2012. Jakarta : IMZ (2012).

Mohsin MIA, Lahsana A, Islmail E., Zakah From Salary and EPF : Issues and Challenges, International Journal of Business and Social Science 2, 1-9 (2011).

Pambudi, A. L., Strategi Pengembangan Pariwisata Alam di Taman Wisata Alam Gunung Pancar. [Tesis] Bogor : MB IPB (2014).

Purnama, H., Strategi Peningkatan Penerimaan Pajak Daerah dari Sektor Kendaraan Bermotor (Studi Kasus UP3AD Kota Semarang II Provinsi Jawa Tengah). [Tesis] Bogor : MB IPB (2013).

Rukmana, Y., Formulasi Strategi Transformasi pada Lembaga Amil Zakat Nasional Dompet Dhuafa. [Tesis] Bogor : MB IPB (2014).

Shalihati, F., Analisis Persepsi dan Sikap Muzakki Terhadap Badan Amil Zakat Nasional Di Kota Jakarta. [Tesis] Bogor : MB IPB (2010).

Said J, Erlane KG, Zawawi SNH, \& Yusof SNS. Composite Performance Measurement for Zakat Organisations. British Journal of Economics, Finance and Management Sciences, Vol. 4 (1), 50-60 (2012).

Sarif S. \& Kamri NA. A Theoretical Discussion of Zakat For Income Generation and Its Fiqh Issues. Shariah Journal, Vol. 17, 457-500 (2009).

Wahid H \& Kader RA. Localization of Malaysian Zakat Distribution : Perceptions of Amil and Zakat Recipients. Seventh International Conference - The Tawhidi Epsitemology : Zakat and Waqf Economy, Bangi 2010.

Wheelen, T. L., \& Hunger, J. D., Strategic Management and Business Policy Toward Global Sustainability. 13th Ed : Pearson Education Inc (2012).

Wibisono, Y., Mengelola Zakat Indonesia. Jakarta : Prenada Media Grup Kencana (2015). 